\title{
Implementation of Local Cultural Values in the Habituation Process of Character Education in the School of the Semarang City
}

\author{
Margi Wahono*, Puji Lestari, Andi Suhardiyanto, Novia Wahyu Wardhani \\ Program Studi PPKn, Universitas Negeri Semarang \\ Semarang, Indonesia \\ *margi85@mail.unnes.ac.id
}

\begin{abstract}
This study aims to explore, review and obtain descriptive description of the process of transformation of local cultural values as an effort to habituate character education or habituation for Junior High School student in Semarang. The approach of this research is qualitative with analytic descriptive method. The data is collected through observation, interview, documentation and literature study. Data analysis techniques is include data collection, reduction, display and conclusions. The research findings show that; local culture contains Pancasila noble values can be used as a means of habituation or character education in Semarang City; appropriate habituation approach can be used for strengthening character education programs; schools that implement culture as a vehicle for strengthening character education, have a better achievement than schools that have not maximally applied school culture as a vehicle for strengthening character education. The recommendations of this research are the education policy stakeholders at the central and regional levels should be more serious in implementing the character education strengthening program; School culture is appropriately used to support the Character Education Strengthening Program.
\end{abstract}

Keywords - local culture; character development; habituation

\section{INTRODUCTION}

Character education through local cultural values at school serves not only as a transfer of knowledge It also aims at implanting moral values, ethical values, aesthetics, local wisdom or noble manner. Hence, familiarizing students with all these becomes an important task to do. This effort is made to minimize any behaviors which do not conform with the applicable values and norms in the society. Local and global civilization, contribute something valuable to civilize him naturally, to shape personal existence and self-image or to the ethnic identities in Indonesia. The knowledge, possessed by the ethnics throughout Indonesia, is one of the strong basic points of the Indonesian culture. In essence, it develops in the realm of the culture, so that the carriers of the culture realize it in whole manner and in a comprehensive way.

The shift in moral values and behaviors towards criminal offence such as school-age delinquency, drug abuse, promisquity in juvenile shows a worrying children's mental preparedness and independence. It is worsened even further by those problems triggered uncontrolled use of technology in cyber world during this last decade. Considering this reality state of affairs, people particularly parents begin to question formal education system As if whether children and teenagers are good or bad is dependent on formal education. Schools and teachers have been the ones to whommany fingers are pointed when issues regarding children and teenagers emerge, even though it has been a common knowledge that the responsibility to shape one's traits does not fall merely to educators in formal educational institutions/schools. Character education ought to be a collective movement which involves the central and regional governments, the society, and/or parents. The current urgency to develop the nation's characters is underlied by such premises as; (1) Philosophically, the national character building constitutes the most essential need in a process to live as a nation since only nations with strong characters and identities will exist; (2) Ideologically, character building is an effort of manifesting Pancasila ideology in people's lives as a nation and a state. Normatively, the national character building constitutes the real embodiment of steps taken to accomplish the national objectives; (3) Historically, the national character building is the core dynamic of a nation's growth which continues to last without a stop within all periods of history, both in collonial era and post-independence one; (4) Socio-culturally, a nation's character building is a necessity for a multicultural nation (Desain Induk Pembangunan Karakter Bangsa Tahun 20102025:1).

Every school should be a comfortable, inspiring place for students, teachers, and/or educational staff. The positive attitude and behavior habituation at schools is a reflection of Pancasila values as the live basic order and should be a part of learning process and culture of each school. Those facts above show the importance to think about the development of education to build student's character at schools. Istianingsih explains that character education is a way of doing anything at school. It does not focus on just certain things, rather it focuses on everything done which affect students [1]. Schools 
are always interested in three abilities, namely skills, knowledge, and characters.

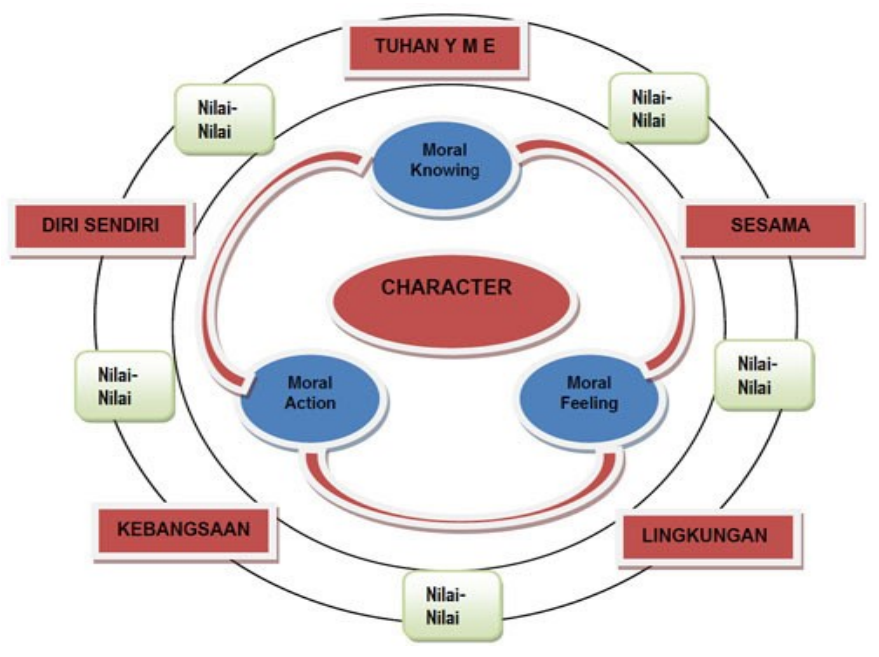

Fig. 1. The relations of moral components in character building.

(Source: Buku Panduan Pendidikan Karakter di SMP [2])

The triangle model above is used to explain moral development. An effective character education does not add a program or a set of programs to the schools. Rather, it transforms the school's culture and life. Character education is a deliberate attempt to help people understand, care, and take actions based on core ethical values. The holistic approach to build character is by building a community which cares about and teaches values through curriculum, class discussions, service learning, explicit teaching in characters and values.

To develop student's character one can familiarize the local society's cultural values to students in classes and schools. This effort of familiarizing values to students is frequently called as habituation, deriving from the word habitus. Pierre F. Bourdieu defines habituation as a process where social values are lived by people, and it is created through a process of socializing values in a long time, thus it settles into a way of thinking and behavior pattern residing in that human self [3]. Habitus according to Bourdieu has indefinite capacity with the products it generates, for example thoughts, perceptions, expressions, utterances, actions and measures. Then, habitus lasts in an everlasting, systematic and non-mechanical way [4]. The development of student's characters through the society's local culture at schools can be done to strengthen the traits and behaviors owned by students.

The strengthening of a nation's characters based on local values is a must in their sustainability-oriented development. In Indonesian society, the development of characters is expected to shape people with a good understanding of virtuous values. From this, they will then be committed to virtues values and finally actually practice them. Novak [5] believes that characters are the harmony between noble values deriving from religious traditions, story books, wise people (in society) and heroes in people's history. Schools as a community constitutes a group of local people where its members interact continuously and have given birth to their own cultural and traditional values. Therefore, schools ought to be a culture neighboorhood. Based on this school condition, it is important then to determine which cultural and traditional values to be the basis of development of values as the materials for character education at schools.

The implantation of local cultural values in schools is the experience and method to help students explore and develop noble values from religions, ethics, humanism, as well as personal and social values so that children will hold virtuous values. Role modelling and habituation are the main elements in the effort of implanting noble values to youth generations. Simultaneous modelling is far more acceptable than thousands of words with no actions. The habituation activity at schools as an effort of implementing character education for students can be done by habituating certain positive behaviors in their daily lives. Habituation is a process of shaping attitudes and behaviors which are relatively settled and automatic in nature through repeated learnings done either collectively or independently. This will also result in a competence. This development of characters through habituation can be done either in scheduled or unscheduled manner and either indoor or outdoor. The habituation activity at school consists of Routine, Spontaneous, Programmed and Modelled Activities [6].

Several studies on the implementation of local cultures in learning bring forth relatively positive results. Wahyudin proves that local cultures play an important role in developing a high-quality learning model at schools, through a process of preparing relevant learning strategies, learning media used, tutor's teaching strategies, how to make a learning society a culture, and managers/organizers [7]. Meanwhile, the results of previous research by Suswandari show that local values and wisdoms from Betawi culture are feasible to be integrated into classroom teaching [8]. More importantly, this research has discussed an alternative learning method which facilitates the combination of local beliefs, values and wisdoms from Betawi culture in classroom context.

This study explores the implementation of character education at schools, based on the culture at those schools by habituating the local culture which represents the main values in its society. The habituation of local cultural values which are integrated in all activities at schools is reflected by the conducive school's atmosphere and environment. It minimizes students' low comprehension of local cultural values which may cause; 1) students' lack of understanding of the condition of environment where they live, for example not knowing the history, geographic condition and economic potentials their regions have. 2). student's lack of pride to their regions. In these students, there grows a perception that everything from the outside is good, and the values existing in their own environment are considered as obsolete. 3) the decreasing togetherness and mutual assistance for they are being replaced by individualism and materialism brought along by globalization, 4). The increasingly weaker sense of brotherhood as can be seen from the increased number of 
student brawl from day to day. 5) minimum appreciation of local culture by people recently coming to the region due to the absence of "when in Rome, do as the Romans do" wisdom or "pindah cai pindah tampian" as known in Sundanese people. This results in the local cultural values being slowly eroded and if this keeps going, these local cultures will eventually vanish from even the society used to own it, since the thought of how to take more benefits have been the one rooted in their minds, rather than focusing on how to co-exist in the midst of diversity.

\section{RESEARCH METHOD}

This research is conducted in Semarang Municipality as its locus, particularly in three junior highs schools or Sekolah Menengah Pertama (SMPs), namely; State SMPs or SMPNs 1, 2 and 13 of Semarang Municipality. This research uses qualitative approach with descriptive method. The data and information in this research are collected using many methods and techniques and they come from many sources. The techniques used to collect data and information are observation, interview, and documentation and literature study. The data analysis refers to the steps taken by Miles and Huberman which consist of three paths of activity simultaneously, including: data collection, data reduction, display and drawing conclusion/verification [9]. To improve the researcher's ability in assessing the accuracy of research results as well as convincing the readers about the accuracy of the research which has been conducted, then various strategies should be used in making validation [10]. Therefore, this research uses three strategies in validating the data, including continuous observation, triangulation and peer-discussion.

\section{RESEARCH RESULTS}

In Semarang Municipality, based on the research conducted in three State SMPs which are the research locus, the following results are obtained. Firstly, the development of character education in SMP is implemented by, among other things, habituation or familiarization of the local society's cultural values. The school atmosphere needs to be built collectively by all of the school's stakeholders based on their respective functions and roles. Both principals, school's employees, teachers, parents, society, and students have some contribution to the development of characters through their attitudes and behaviors which come from local cultures at schools. Habituation is done in two ways, namely classroom learning and school society's activities or school activities. The habituation strategy beyond the learning hours is done through the implementation of the nation's character education values in school's cultures, rules and arrangement of schools/classes, role-modelling, and habituation of school members. Meanwhile, the strategy during classroom learning, for example in Civics course at schools, is done by integrating the local cultural values in lesson plans of the newly-revised 2013 curriculum (2017). In learning lesson plan, teachers include the character values of attitude and behavior they want their students to get accustomed to by considering the
Javanese cultural values. An example of Javanese values which are full of meanings, teachings and ethics to live in society is "Gayuting lathi, ati, pakarti" which means to synergize what one thinks, says and does. This value has significant influence on academic members at those schools with their respective roles. Habituating one's own attitudes and behaviors, i.e. teachers should be consistent in what they say and they do, to be a role model for their students. The same should also be done by students, they should get themselves accustomed with being consistent in what they think, say and do. The importance of role-modelling in implanting virtuous values is even clearer exemplified by the saying "Guru kencing berdiri, murid kencing berlari" which in some sense is equivalent to the English "monkey see, monkey do". In daily life, it can be seen from each individual's habits. "Guyub rukun agawe santoso" or living in harmony will bring happiness. "Ojo dumeh kuoso" do not be arrogant just because you think you have the power, people have to be "andhap asor" (low profile), have some unggah ungguh (manner) and so forth. These Javanese sentences, wisdoms and ethics are printed in banners made by the school and they are also implemented. In the three schools which are the locus of this research, the Character Education Reinforcement Movement at school is defined as a manifestation of Mental Revolution Movement and an integral part of Nawacita (nine key programs) at the same time. It is important to place character education as the main or core dimension of national education, hence character education will also be the main axis of the implementation of elementary and secondary education. Integrating, deepening, expanding, and at the same time harmonizing various programs and activities of character education which have been done through a transformation with local cultures, because in principle schools cannot be separated from the local wisdoms of the place it is situated in.

Secondly, the habituation of local cultures in developing characters influences the successful implementation of character development of students at State SMPs 1, 2, and 13 of Semarang Municipality. In these three schools where the research is conducted, students do learn virtuous values. Teachers play strategic roles in this process. The process of making values a culture and empowerment process which include role-modelling, learning, habituation, and reinforcement have been developed systematically, holistically, and dynamically even though teachers think there are still some weaknesses. The academic and non-academic lives at schools can be more clearly experienced after the habituation of local culture application in students, teachers and all members of these schools are implemented during the last one year. This can be traced from the Counseling and Guidance teachers' note about the decreased number of students who violate the school's rules. Students' juvenile has been mitigated, the communication occurs between students and teachers and other relevant parties.

Thirdly, any school with good environment will be faster in shaping its students' characters. The school which has 
implemented character development through local culture habituation has relatively better students' achievement than those schools which have not implemented character development through local culture habituation. The research shows that the more the school develop the education of character existing the school's culture, the better their student's academic achievement would be. The school is aware that to make their school a developed, high-achieving one, they will need the support and cooperation with many parties. In this case, the school periodically convenes a workshop or meeting which involves all school members to exchange their thoughts regarding the development and advancement of education in schools. This gives birth to the character of cooperation among all stakeholders in schools, be it principals, teachers, students and even the school's security guards. As a nation, for Indonesia and particularly Javanese people, speech is a reflection of oneself for every individual, when the words they say are polite and friendly, this shows that these individuals have good characters and traits in terms of their behavior. The integration of local cultural values creates an interactive, inspiring, fun, challenging learning as well as motivates students to actively participate and provide enough space for innovation, creativity and independence according to their talents, interest to develop student's physical and psychological states.

Habituation is applied as an approach in the character education teaching and learning process, particularly character education which integrate and transform local cultures into its learning process at schools. All members of the school are habituated to comply with the procedures to implement the nationa's character education values. Thus, when it begins with habituation, then a culture existing in the school will manifest and it enables the character education through local culture to develop students' characters at school, which eventually will be realized when these students join the society in common. Character education is not merely an educational trend or the school's latest fad, it is a fundamental dimension of good teaching, an abiding respect for the intellect.and spirit of the individual. The Character Education Partnership was launched in March 1993, as a national coalition committed to putting character development at the top of the nation's educational agenda [11]. Members of the Partnership are made up of representatives from business, labor, government, parents, youth, faith communities, and the media $[12,13]$.

\section{CONCLUSION}

The conclusions of this studi is; 1). The characters in students' self can be formed by applying local cultures which are integrated into a process of interaction at schools and in classroom learning; 2) Teachers play essential roles in shaping students' characters at school by integrating and transforming local cultural values into learning and beyond learning process; 3) Schools with good atmosphere will be faster in shaping the students' character. School's culture plays an important role in developing students' characters at school. The schools which have school's culture and have developed it in their development of character inside students have better academic and non-academic achievements than those which have not implemented school's culture in developing their students' characters.

\section{REFERENCES}

[1] Istiningsih. 2016. Character Education of the Most Developed Countries in ASEAN. http://www.asianonlinejournals.com/index.php/JEELR/article/view/657. Diakses Tanggal 1 Februari 2018

[2] Kementerian Pendidikan Nasional. 2011. Panduan Pendidikan Karakter Di Sekolah Menengah Pertama. Jakarta: Direktorat Pembinaan Sekolah Menengah Pertama.

[3] Jenkins, 1992: 55.

[4] Hidrawati, 2017: 6.

[5] Lickona, Thomas, Educating for Character: How Our Schools Can Teach Respect and Responsibility. New York: Bantam Books, 1992.

[6] Susilana, rudi, et al. The Malaysian Online Journal of education Science. Development of Quality Assurance System in Culture and Nation Character Education in Primary Education in Indonesia. https://files.eric.ed.gov/fulltext/EJ1086212.pdf (diakses tanggal 22 januari 2018)

[7] Wahyudin, uyu. 2016. The Quality of a 'Local Values Based' Fuctional Literacy Program: Its Contribution to the Improvement of the Learner's Basic Competencies. https://files.eric.ed.gov/fulltext/EJ1060859.pdf. (diakses tanggal 22 januari 2018)

[8] Suswandari. 2017. Incorporating Beliefs, Values and Local Wisdom of Betawi Culture in a Character-Based Education through a Design-Based Research https://www.researchgate.net/publication/320136921 Incorporating Bel iefs_Values and_Local_Wisdom_of_Betawi_Culture_in_a_Character based_Education_through_a_Design Based_Research (diakses tanggal 1 Februari 2018)

[9] Miles, Mattew B dan Amichael Huberman. 2007. Analisis Data Kualitatif Buku Sumber tentang Metode-Metode Baru. Terjemahan Tjetjep Rohendi Rohisi. Jakarta: Universitas Indonesia.

[10] Creswell, John. W. 2013. Research Design: Qualitative and Mixed Methods Approach. Thousand Oak: Sage Publication Inc.

[11] Ryan, 1996

[12] Lickona, Thomas; Schaps, Eric, dan Lewis, Catherine. Eleven Principles of Effective Character Education. Character Education Partnership, 2007.

[13] Nancy Burke, et.al. Building Character Education in our Schools to Enhance the Learning Environment. Saint Xavier University \& Skylight Professional Development U.S. DEPARTMENT OF EDUCATION Field-Based Masters Program 